\title{
GSK-3 $\beta$ suppresses the proliferation of rat hepatic oval cells through modulating Wnt/ $\beta$-catenin signaling pathway
}

\author{
Xiao-ke $\mathrm{JI}^{1}$, Yuan-kang XIE ${ }^{2}$, Jun-qiao ZHONG ${ }^{3}$, Qi-gang XU ${ }^{1}$, Qi-qiang ZENG ${ }^{1}$, Yang WANG ${ }^{1}$, Qi-yu ZHANG ${ }^{1, *}$, \\ Yun-feng SHAN ${ }^{1, *}$ \\ ${ }^{1}$ Department of General Surgery, the First Affiliated Hospital of Wenzhou Medical University, Wenzhou 325000, China; ${ }^{2}$ Department \\ of General Surgery, the First Affiliated Hospital of Gannan Medical College, Ganzhou 341000, China; ${ }^{3}$ Department of General Surgery, \\ Ganzhou People's Hospital, Ganzhou 341000, China
}

Aim: Glycogen synthase kinase $3 \beta$ (GSK-3ß) plays a crucial role in hepatic biology, including liver development, regeneration, proliferation and carcinogenesis. In this study we investigated the role of GSK-3 $\beta$ in regulation of growth of hepatic oval cells in vitro and in liver regeneration in partially hepatectomized rats.

Methods: WB-F344 cells, the rat hepatic stem-like epithelial cells, were used as representative of oval cells. Cell viability was examined using a WST-8 assay. The cells were transfected with a recombinant lentivirus expressing siRNA against GSK-3 3 (GSK-

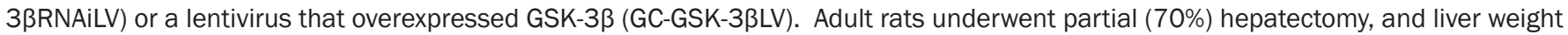
and femur length were measured at $d 7$ after the surgery. The expression of GSK-3 $\beta$, phospho-Ser ${ }^{9}-G S K-3 \beta, \beta$-catenin and cyclin D1 was examined with immunoblotting assays or immunohistochemistry.

Results: Treatment of WB-F344 cells with the GSK-3ß inhibitor SB216763 ( 5 and $10 \mu \mathrm{mol} / \mathrm{L}$ ) dose-dependently increased the levels of

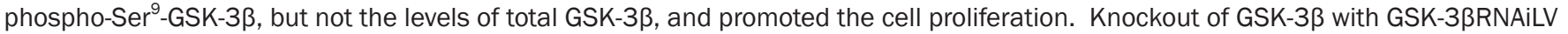
increased the cell proliferation, whereas overexpression of GSK-3 $\beta$ with GC-GSK-3 3 LV decreased the proliferation. Both SB216763

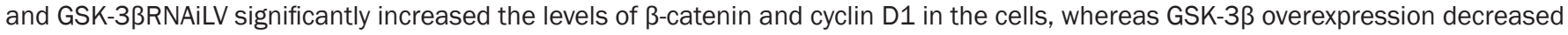
their levels. In rats with a partial hepatectomy, administration of SB216763 $(2 \mathrm{mg} / \mathrm{kg}$, ip) significantly increased the number of oval cells, the levels of phospho-Ser ${ }^{9}$-GSK-3 $\beta, \beta$-catenin and cyclin D1 in liver, as well as the ratio of liver weight to femur length at $d 7$ after the surgery.

Conclusion: GSK-3ß suppresses the proliferation of hepatic oval cells by modulating the Wnt/ $\beta$-catenin signaling pathway.

Keywords: liver; hepatectomy; liver regeneration; oval cells; WB-F344 cells; GSK-3ß; Wnt/ß-catenin signaling pathway; SB216763; SiRNA

Acta Pharmacologica Sinica (2015) 36: 334-342; doi: 10.1038/aps.2014.150; published online 9 Feb 2015

\section{Introduction}

The liver has a remarkable capacity to regenerate after toxic injury or surgical resection. Oval cells are facultative stem cells in the adult liver but are activated only if hepatocyte proliferation is inhibited ${ }^{[1-3]}$. These cells can differentiate into hepatocytes and bile duct cells and can thus restore the architecture and function of the damaged liver tissue ${ }^{[4-7]}$. Oval cells are usually present in normal fetal livers but have been implicated in hepatic carcinogenesis in a variety of hepatic

\footnotetext{
* To whom correspondence should be addressed.

E-mail surgzhang2010@163.com (Qi-yu ZHANG); shanyf2009@163.com (Yun-feng SHAN)

Received 2014-06-17 Accepted 2014-10-23
}

pathologies $^{[8,9]}$.

Glycogen synthase kinase-3 $\beta$ (GSK-3 $\beta$ ) is a constitutively active serine-threonine kinase that was originally identified as a key regulatory enzyme in glucose metabolism ${ }^{[10]}$. It was subsequently found to be involved in a variety of cellular pathways, depending on its substrates ${ }^{[10-12]}$. Regulation of the Wnt/ $\beta$-catenin signaling is only one of its diverse functions ${ }^{[10,11]}$. GSK-3 $\beta$ activity is increased by the site-specific phosphorylation of Tyr216, whereas the phosphorylation of Ser9 inhibits GSK-3 $\beta$ activity ${ }^{[12]}$. A growing body of research has identified a critical role of GSK-3 $\beta$ signaling in various aspects of hepatic biology, including liver development, regeneration, proliferation, and hepatocellular carcinoma (HCC) pathogenesis ${ }^{[13-18]}$. However, there have been relatively few reports that connect 
GSK-3 $\beta$ signaling with liver oval cells.

WB-F344 cells are hepatic stem-like epithelial cells of rat origin and were first isolated from the liver of an adult male Fischer-344 rat. After transplantation into the liver of adult syngeneic German strain Fischer-344 rats deficient in the bile canalicular enzyme dipeptidyl peptidase IV (DPP-IV), WB-F344 cells can be integrated into hepatic plates and differentiate into mature hepatocytes ${ }^{[19]}$. When treated with sodium butyrate and cultured on Matrigel, WB-F344 cells differentiate into the biliary phenotype ${ }^{[20]}$. For these reasons, WB-F344 cells have been used as an in vitro representative of oval cells ${ }^{[21,22]}$.

In the present study, we examined the effects of GSK-3 $\beta$ on the growth of cultured WB-F344 cells and investigated changes in the downstream targets of GSK-3 $\beta$. The effects of GSK-3 $\beta$ manipulation in liver regeneration were also examined in rats using 2-acetylaminofluorine and a partial hepatectomy $(2-\mathrm{AAF} / \mathrm{PH})^{[23]}$.

\section{Materials and methods Cell culture}

WB-F344 and 293T cells were cultured in Dulbecco's modified Eagle's medium (GIBCO; Carlsbad, CA, USA) containing 10\% fetal bovine serum (GIBCO) in a humidified atmosphere with $5 \% \mathrm{CO}_{2}$ and $95 \%$ air at $37^{\circ} \mathrm{C}$.

\section{Preparation of lentiviruses}

For the construction and production of a GSK-3 $\beta$ RNAi lentivirus, the rat GSK-3 $\beta$ sequence (gsk-3 $\beta$, NM_032080, rat) was searched for suitable siRNA target sequences. The identified sequence (5'-CCACTCAAGAACTGTCAAGTA-3') was converted into a short-hairpin RNA (shRNA), followed by the addition of Age I and EcoR I restriction sites at the 5'- and 3 '- ends, respectively. The oligonucleotide was annealed and then inserted into the pGCSIL-GFP vector for the transformation of DH5a-competent Escherichia coli cells. The insertion of the shRNA cassette was confirmed by restriction enzyme digestion and DNA sequencing. A scrambled siRNA sequence (5'-TTCTCCGAACGTGTCACGT-3') was used as a negative control (NC). The recombinant vector pGCSILGFP and packaging helper plasmids, including pHelper 1.0 and pHelper 2.0, were co-transfected into the 293T cells using Lipofectamine 2000 reagent (Invitrogen; Carlsbad, CA, USA). The medium was replenished $8 \mathrm{~h}$ after the transfection. The culture supernatant was collected $48 \mathrm{~h}$ after the transfection, centrifuged at $4000 \times g$ for $10 \mathrm{~min}$ at $4{ }^{\circ} \mathrm{C}$ to remove cell debris, filtered through a $0.45-\mu \mathrm{m}$ filter, and concentrated. The titer of the recombinant lentiviruses (GSK-3 $\beta$ RNAiLV and NC-GFP) was $1.5 \times 10^{9}$ and $1.0 \times 10^{9} \mathrm{TU} / \mathrm{mL}$, respectively.

For the construction and production of a lentivirus overexpressing GSK-3 $\beta$, cDNA for GSK-3 $\beta$ was amplified using primers containing the restriction site for Age I (sense: 5'-GAGGATCCCCGGGTACCGGTCGCCACCATGTCGGGGCGACCGAGAACC-3', antisense: 5'-TCACCATGGTGGCGACCGGGGTAGAGTTGGAGGCTGATG-3'). After digestion with Age I, the cDNA was inserted into the pGC-FU vector. The recombinant vector, and vectors pHelper 1.0 and pHelper 2.0 were co-transfected into $293 \mathrm{~T}$ cells to produce GC-GSK-3ßLV. GC-FU-GFP was used as a negative control.

Lentivirus transduction and GSK-3 $\beta$ inhibitor treatment

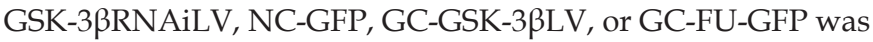
added into WB-F344 cell culture with $5 \mu \mathrm{g} / \mathrm{mL}$ Polybrene at a multiplicity of infection (MOI) of 20-30. The cells were harvested $72 \mathrm{~h}$ post-infection. For GSK-3 $\beta$ inhibition, SB216763 (Sigma; St Louis, MO, USA) or the vehicle control dimethyl sulfoxide (DMSO) was added to WB-F344 cell culture at the indicated concentrations for $72 \mathrm{~h}$.

\section{In vitro cell proliferation assay}

WB-F344 cells were seeded in 96-well plates at a density of 2000 cells per well. The treatment was started after $24 \mathrm{~h}$ incubation, and lasted for $72 \mathrm{~h}$. The number of viable cells was determined using a WST-8 \{4-[3-(4-iodophenyl)-2-(4nitrophenyl)-2H-5-tetrazolio]-1,3-benzene disulfonate\} assay kit (Cell Counting Kit-8; Dojindo Laboratories, Kumamoto, Japan). The optical density was measured using a microtiter plate reader. The data are expressed as the mean plus or minus the standard deviation ( $n=5$ per treatment condition).

\section{Animal studies}

Male Sprague-Dawley rats $(n=12)$, each weighing 110-120 g, were obtained from the Experimental Animal Center of Wenzhou Medical University. The study protocol was approved by the Animal Care and Use Committee at the authors' affiliated institution (The Ethics Committee of The First Affiliated Hospital of Wenzhou Medical University). The experiments were carried out in accordance with the Guide for Care and Use of Laboratory Animals (NIH publication 86-23, revised 1985). Animals were housed in a controlled environment with a 12-h light/dark cycle (lights on from 6:00 AM to 6:00 PM) at a constant temperature $\left(22-25^{\circ} \mathrm{C}\right)$ with ad libitum access to food and water.

For 2-AAF/PH, rats received a daily dose of 2-AAF (Sigma; $20 \mathrm{mg} / \mathrm{kg}$, by gavage) suspended in corn oil (1\%) for 4 consecutive days. $\mathrm{PH}(70 \%)$ was carried out on the next day. The day after $\mathrm{PH}$, treatment with 2-AAF was resumed and lasted for 7 additional days. Treatment with SB216763 (1 or $2 \mathrm{mg} / \mathrm{kg}$, intraperitoneally) or the vehicle $(200 \mu \mathrm{L} 75 \%$ DMSO) started the day before $\mathrm{PH}$ and then on $\mathrm{d} 1,3$, and 5 after $\mathrm{PH}(n=3$ per condition). A group of three rats receiving $200 \mu \mathrm{L}$ of normal saline (NS) was included as an additional control. Animals were euthanized on $\mathrm{d} 7$ after $\mathrm{PH}^{[24]}$ and liver weight and femur length were measured.

\section{Western blotting assays}

Frozen liver tissues and WB-F344 cells were lysed using a standard kit (Fermentas; Vilnius, Lithuania) with fresh protease (Fermentas) and phosphatase inhibitor cocktails (Roche; Mannheim, Germany). The lysate was centrifuged at $18000 \times \mathrm{g}$ at $4{ }^{\circ} \mathrm{C}$ for $15 \mathrm{~min}$. Western blotting was carried out using 
one of the following primary antibodies: anti-GSK-3 $\beta$ (Santa Cruz Biotechnology; Santa Cruz, CA, USA), anti-phosphoSer-GSK-3 $\beta$, anti- $\beta$-catenin, anti-cyclin D1 or anti-GAPDH antibody (all from Cell Signaling Technology; Danvers, MA, USA). Horseradish peroxidase-conjugated secondary antibodies were from Jackson ImmunoResearch (West Grove, PA, USA). Protein bands were visualized using the Super-Signal West Pico Chemoluminescent Substrate (Pierce; Rockford, IL, USA) and analyzed using Bio-Rad Quantity One 1-D analysis software (v.4.6.2).

\section{Immunohistochemistry}

Sections were de-paraffinized with xylene and rehydrated with gradient alcohol. Endogenous peroxidase was quenched with $3 \% \mathrm{H}_{2} \mathrm{O}_{2}$ for $10 \mathrm{~min}$ at room temperature. Antigen retrieval was performed by treating the slide with citrate buffer in a microwave for $15 \mathrm{~min}$. The slides were blocked in 5\% goat serum albumin and incubated in a moist chamber with a mouse monoclonal antibody against OV-6 (R\&D Systems; Minneapolis, MN, USA) at $4{ }^{\circ} \mathrm{C}$ overnight. After a brief wash in PBS, the slides were treated with goat anti-mouse antibody (EnVision Kits, DAKO) for $30 \mathrm{~min}$ at $37^{\circ} \mathrm{C}$. After washing with PBS, the slide was developed in a freshly prepared $0.05 \%$ diaminobenzidine solution (DAB; Sigma) and counterstained with hematoxylin. Three non-overlapping microscopic fields of each section were chosen for counting OV-6-positive oval cells, and the average number of oval cells was used as an index of oval cell proliferation.

\section{Statistical analysis}

The data are presented as the mean \pm standard deviation (SD) and were analyzed with a two-tailed Student's $t$-test or oneway ANOVA test. $P$ values $<0.05$ were considered statistically significant.

\section{Results}

Inactivation of GSK-3 $\beta$ by SB216763 promotes the proliferation of WB-F344 cells

Immunoblotting assays revealed that SB216763 caused a marked dose-dependent increase in the phosphorylation of inactive GSK-3 $\beta$ at Ser $^{9}$ (phospho-Ser-GSK-3 $\beta$ ) (Figure 1A and 1B) but not that of total GSK-3 $\beta$ protein (Figure 1C). CCK-8 assays showed that SB216763 markedly promoted the growth of WB-F344 cells (Figure 1D).

Immunoblotting assays showed that GSK-3 $\beta$ RNAiLV markedly suppressed the expression of GSK-3 $\beta$ in WB-F344 cells (Figure 2A-2C). GC-GSK-3 $\beta \mathrm{LV}$ increased the expression of GSK-3 $\beta$ (Figure 2D and 2E). CCK-8 assays showed that the downregulation of GSK-3 $\beta$ with GSK-3 $\beta$ RNAiLV caused a significant increase in the proliferation of WB-F344 cells (Figure $2 \mathrm{~F})$. In contrast, GSK-3 $\beta$ overexpression markedly suppressed the proliferation of WB-F344 cells (Figure 2F).
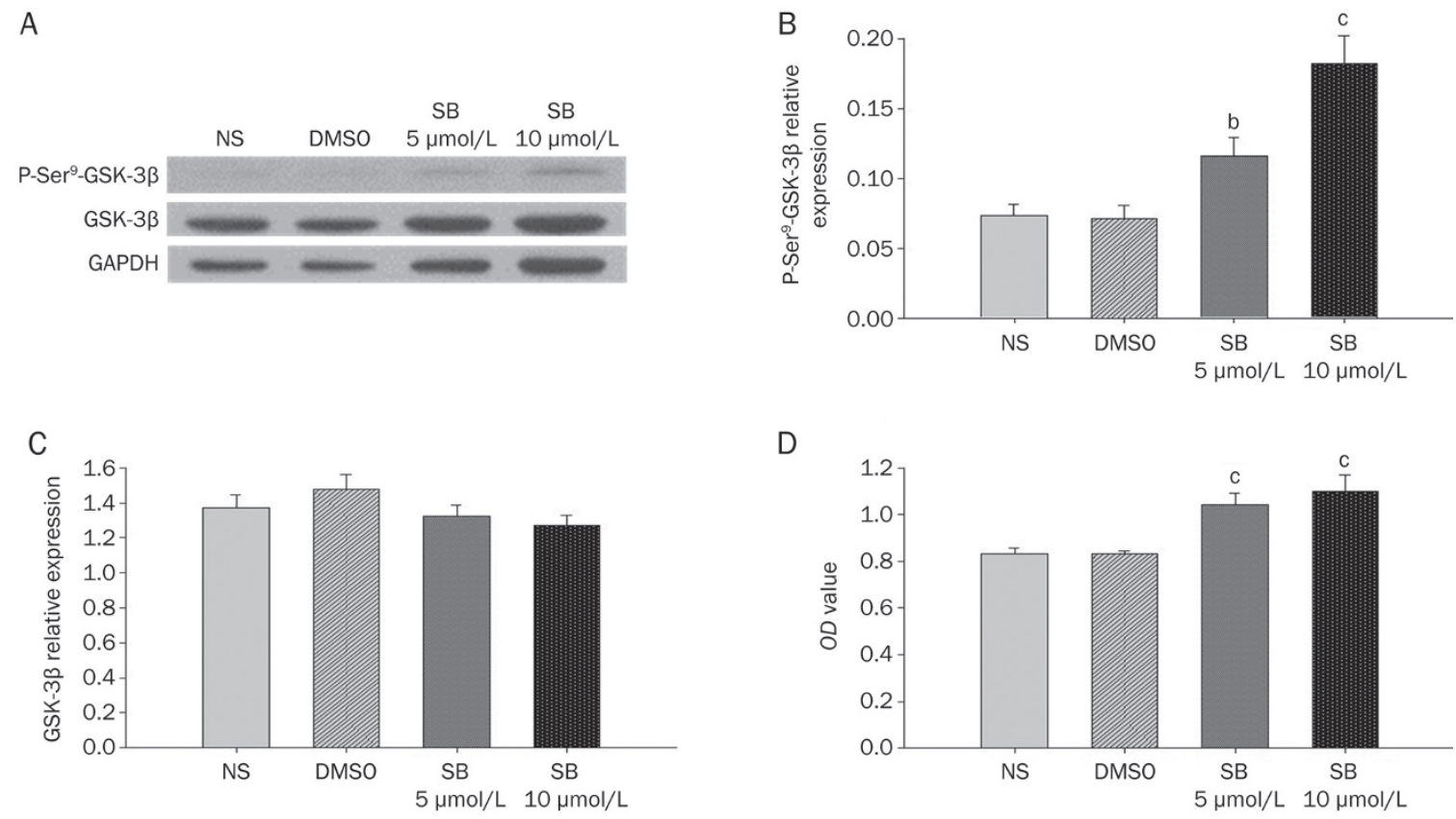

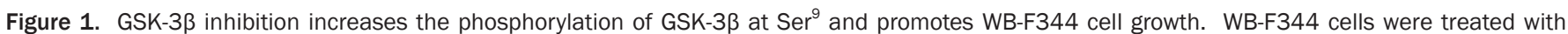
normal saline (NS), dimethyl sulfoxide (DMSO), 5 or $10 \mu \mathrm{mol} / \mathrm{L}$ of the GSK-3ß inhibitor SB216763. After $72 \mathrm{~h}$, cellular lysates were prepared for

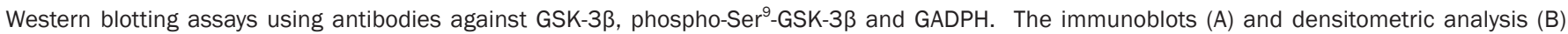
show increased levels of phospho-Ser-GSK-3 $\beta$ following treatment with SB216763 while the level of GSK-3 $\beta$ was not significantly changed (C). CCK8 viability assays show that SB216763 markedly promotes the proliferation of WB-F344 cells (D). ${ }^{b} P<0.05,{ }^{c} P<0.01$ vs NS or DMSO. The data in (B-D) are represented as the mean $\pm S D$ of at least three independent experiments performed in quintuplicate. 
A
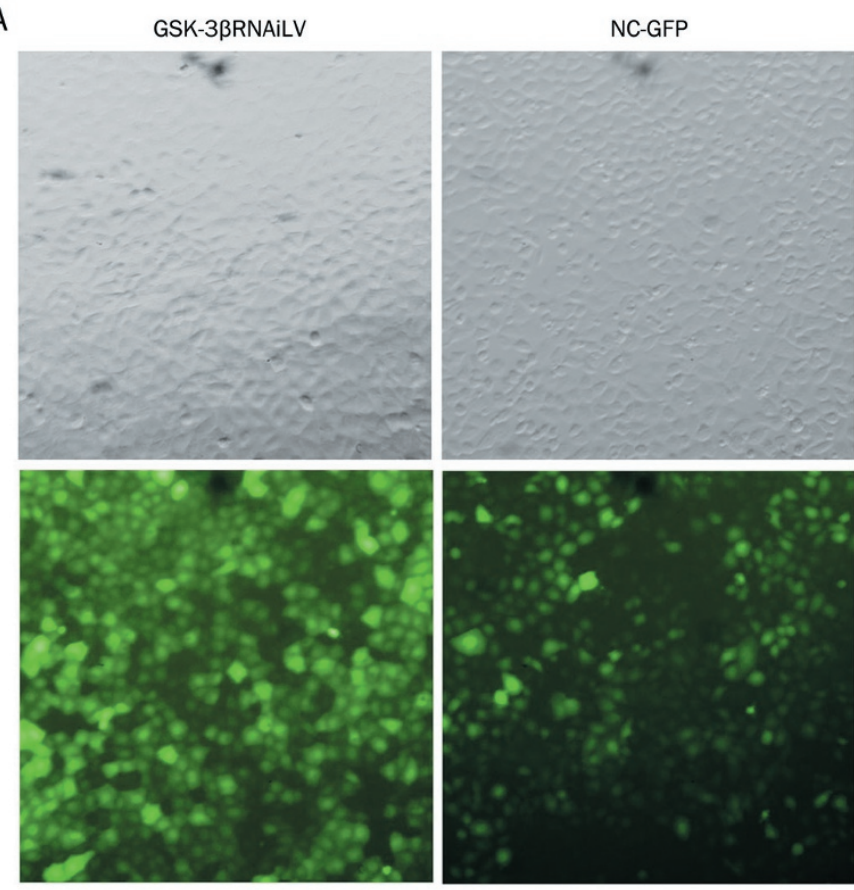

B

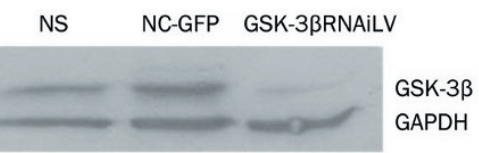

D
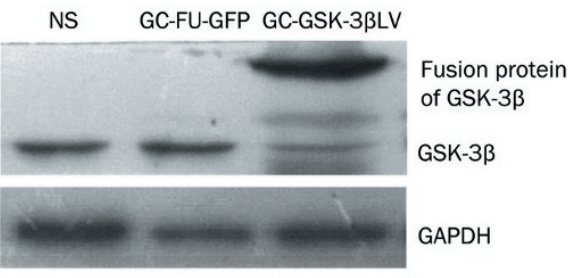

GAPDH

$\mathrm{F}$

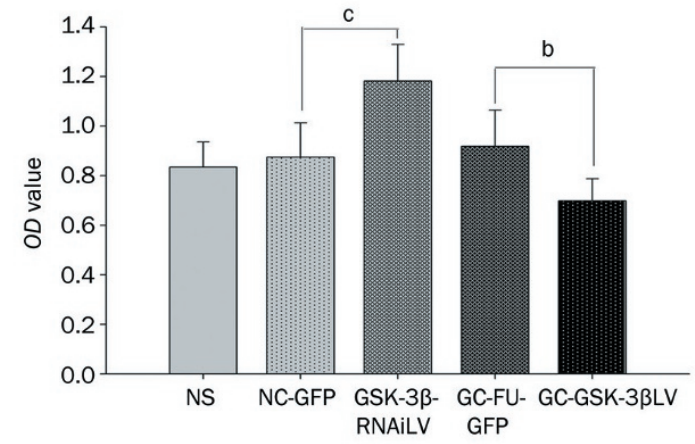

GC-GSK-3ßLV
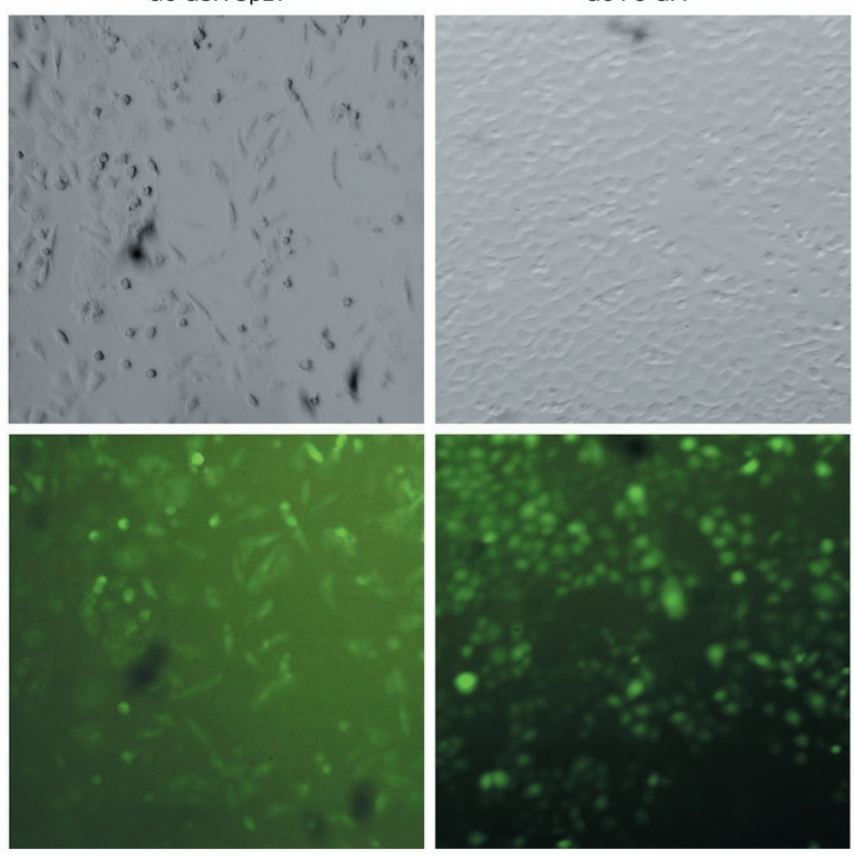

C

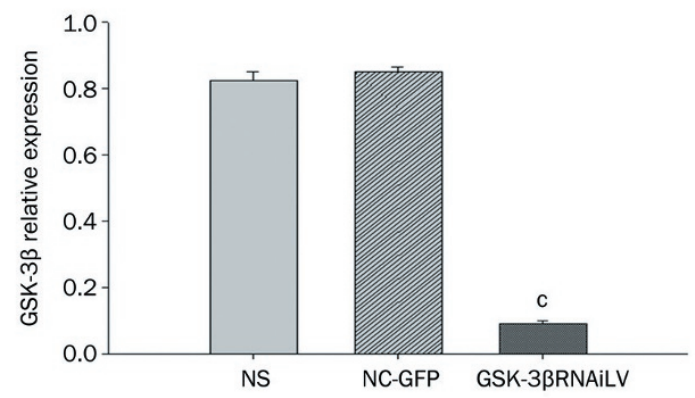

E

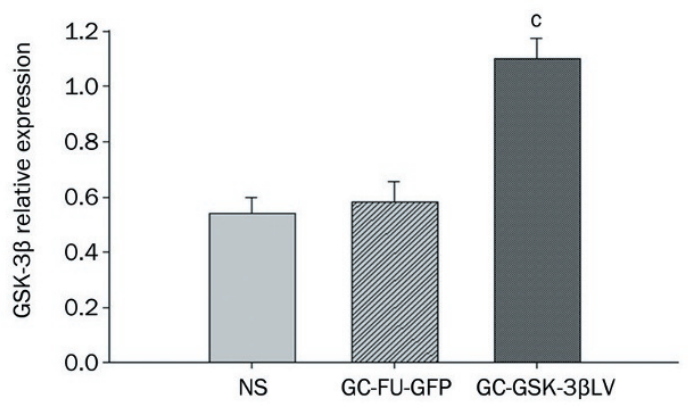

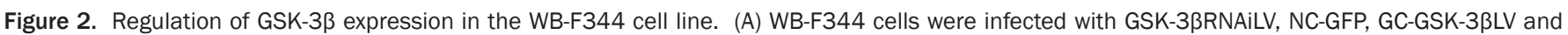

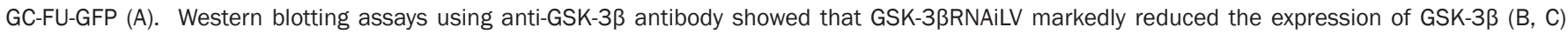

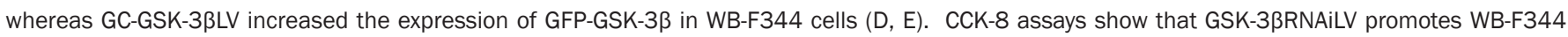
cell proliferation while GC-GSK-3ßLV suppresses the proliferation (F). ${ }^{b} P<0.05,{ }^{c} P<0.01$ vs NS or GFP controls. The data in (C, E, and F) are represented as the mean $\pm S D$ of at least three independent experiments performed in quintuplicate. 
GSK-3 $\beta$ modulates Wnt/ $\beta$-catenin signaling in WB-F344 cells

As expected, the inhibition of GSK-3 $\beta$ with SB216763 increased the expression of $\beta$-catenin in a dose-dependent manner, as well as its downstream target cyclin D1 (Figure 3A-3C). Similarly, the downregulation of GSK-3 $\beta$ with GSK-3 $\beta$ RNAiLV also increased the expression of $\beta$-catenin and cyclin D1. GSK-3 $\beta$ overexpression with GC-GSK-3 $\beta$ LV decreased the levels of $\beta$-catenin and cyclin D1 (Figure 3D-3G).

A

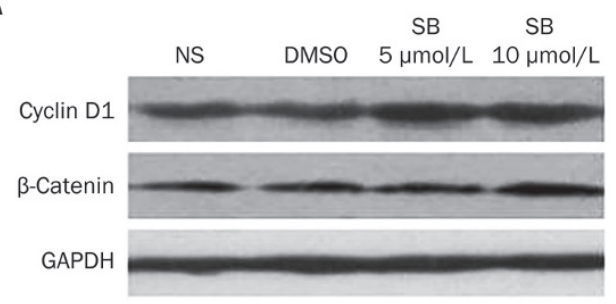

C

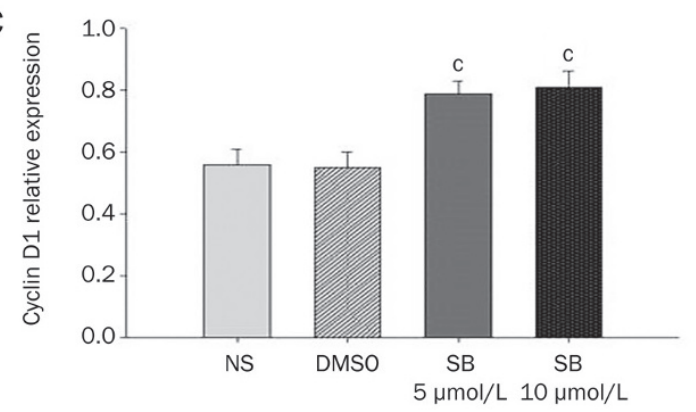

$\mathrm{E}$

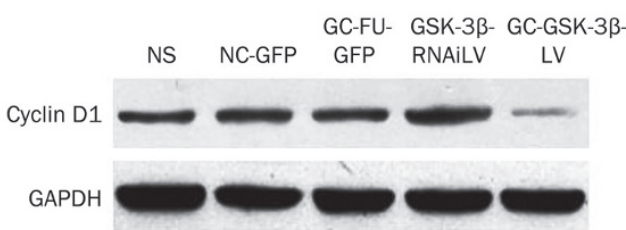

G

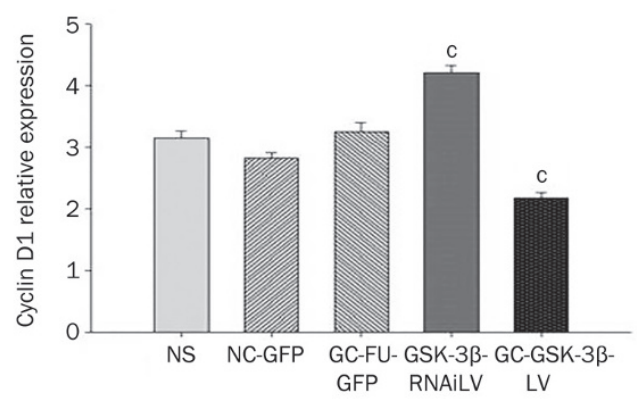

Inhibition of GSK-3 $\beta$ enhances the proliferation of oval cells by modulating $\mathrm{Wnt} / \beta$-catenin signaling in vivo

Western blot analysis demonstrated that GSK-3 $\beta$ inhibition increased the level of phospho-Ser ${ }^{9}-$ GSK-3 $\beta$ in the liver but not the total GSK-3 $\beta$ (Figure 4A-4C). SB216763 markedly increased the ratio of liver weight to femur length $(P<0.05$ vs DMSO vehicle; Table 1). GSK-3 $\beta$ inhibition significantly increased the number of oval cells in the liver after $\mathrm{PH}$

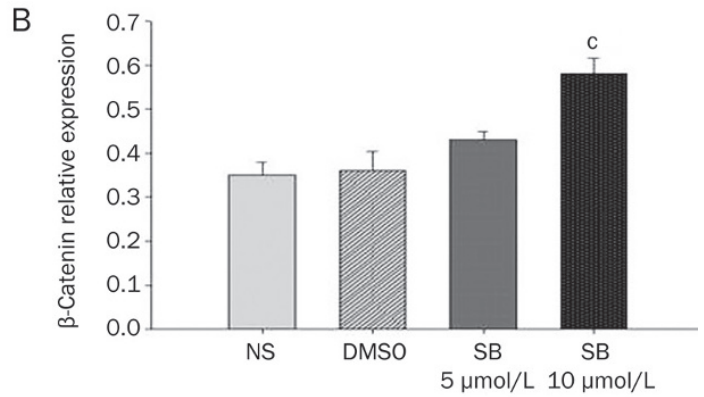

D

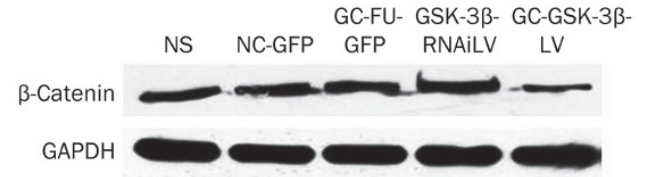

$\mathrm{F}$

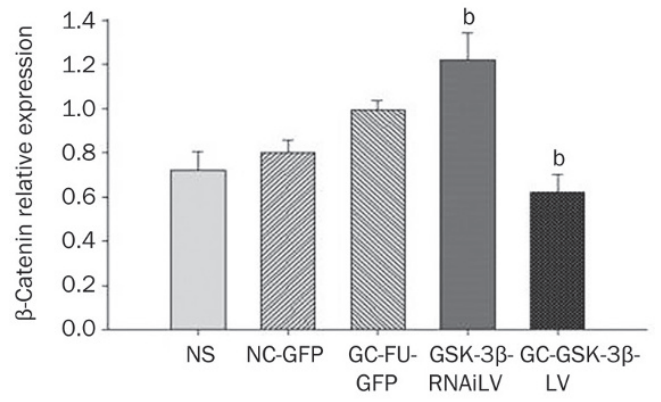

Figure 3. GSK-3 $\beta$ modulates Wnt/ $\beta$-catenin signaling in WB-F344 cells. (A-C) WB-F344 cells were treated as in Figure 1 and (D-G) as in Figure 2 . Western blotting assays using antibodies against $\beta$-catenin and cyclin D1 were performed to examine their expression. ${ }^{b} P<0.05$, ${ }^{\mathrm{c}} P<0.01$ vs NS or GFP controls. The data in (B, C, F, and $\mathrm{G}$ ) are represented as the mean $\pm \mathrm{SD}$ of at least three independent experiments performed in quintuplicate. 
A

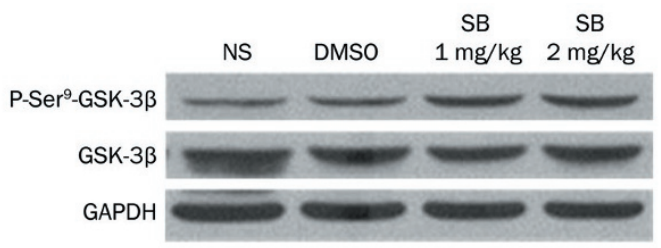

B

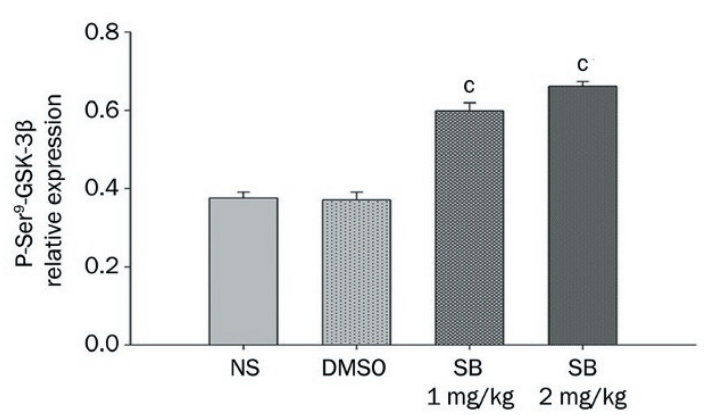

D
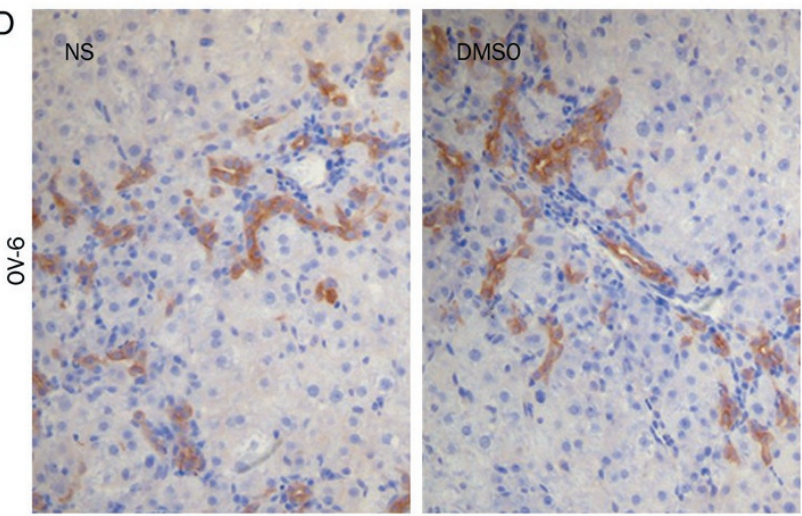

E

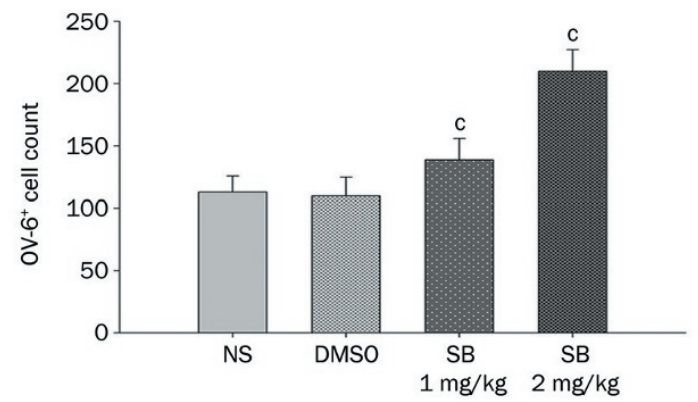

G

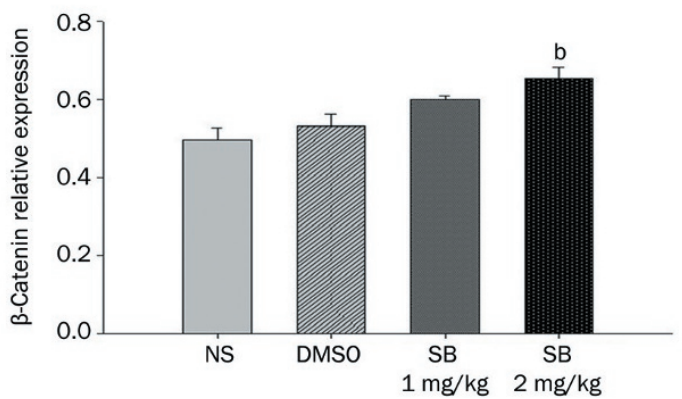

C

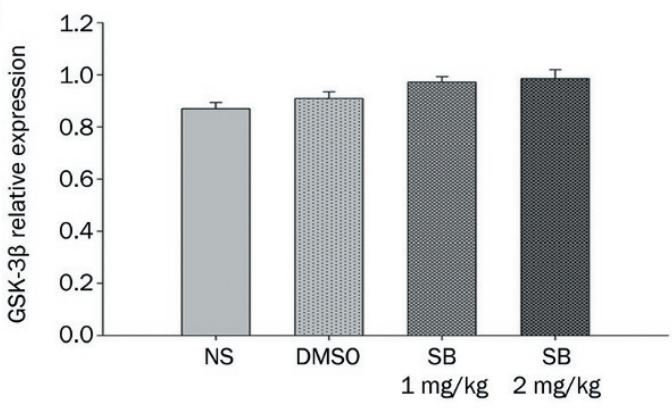

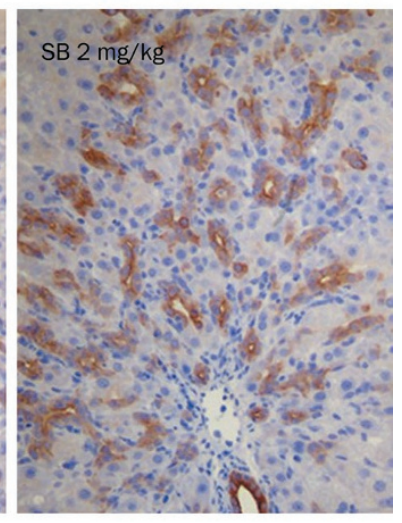

F
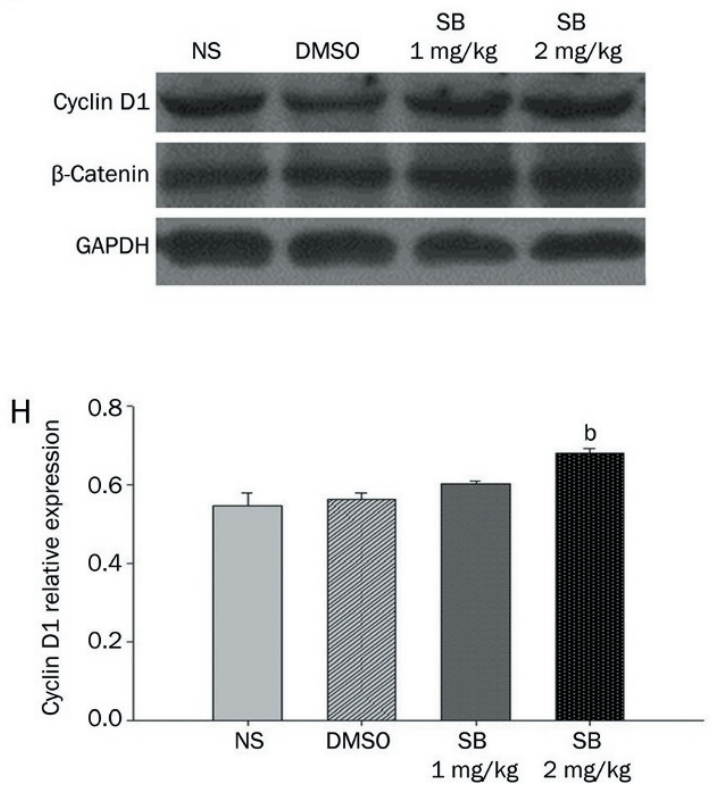

Figure 4. Inhibition of GSK-3ß enhances proliferation of oval cells through Wnt/ $\beta$-catenin signaling. (A) Western blot analysis of GSK-3 $\beta$ and phosphoSer ${ }^{9}$-GSK-3 $\beta$ in the liver at d 7 post-operation. (B) The level of phospho-Ser ${ }^{9}$-GSK-3 $\beta$ was elevated after treatment with SB216763. (C) The level of total GSK-3 $\beta$ was not significantly changed after treatment with SB216763. (D) Immunohistochemical staining (OV-6) of 2-acetylaminofluorine (2-AAF)treated and partially hepatectomized rat liver. (E) The proliferation of oval cells was enhanced by treatment with SB216763. (F) Western blot analysis of $\beta$-catenin and cyclin D1 in the liver at d 7 post-operation. (G) The level of $\beta$-catenin was elevated after treatment with SB216763. (H) The level of cyclin D1 was elevated after treatment with SB216763. ${ }^{\mathrm{b}} P<0.05,{ }^{\mathrm{c} P}<0.01$. 
Table 1. Effect of SB216763 on liver regeneration following partial hepatectomy. ${ }^{\mathrm{b}} P=0.022$ vs the normal saline or dimethyl sulfoxide group.

\begin{tabular}{lccc}
\hline Group & $\begin{array}{c}\text { Liver weight } \\
(\mathrm{g})\end{array}$ & $\begin{array}{c}\text { Femur length } \\
(\mathrm{mm})\end{array}$ & $\begin{array}{l}\text { Liver weight/ } \\
\text { femur length }\end{array}$ \\
\hline $\begin{array}{l}\text { Normal saline } \\
\text { Dimethyl sulfoxide }\end{array}$ & $8.60 \pm 0.52$ & $28 \pm 1.0$ & $0.31 \pm 0.01$ \\
SB216763 & $8.73 \pm 0.81$ & $27.3 \pm 1.1$ & $0.32 \pm 0.02$ \\
$1 \mathrm{mg} / \mathrm{kg}$ & $9.33 \pm 0.50$ & $28 \pm 1.0$ & $0.33 \pm 0.01$ \\
$2 \mathrm{mg} / \mathrm{kg}$ & $10.80 \pm 0.26$ & $28.3 \pm 0.5$ & $0.38 \pm 0.01^{\mathrm{b}}$ \\
\hline
\end{tabular}

$(P<0.05)$ (Figure 4D-4E). The inhibition of GSK-3 $\beta$ with SB216763 also markedly increased the levels of $\beta$-catenin and cyclin D1 (Figure 4F-4H).

\section{Discussion}

The adult liver harbors stem cells that can be activated upon severe liver injury to give rise to both hepatocytic and biliary epithelial cell lineages ${ }^{[25]}$. The present study demonstrated that GSK- $3 \beta$ signaling plays an important role in the proliferation of oval cells. Previous studies in mice have shown that disruption of the GSK-3 $\beta$ gene results in embryonic lethality because of severe mid-gestation liver degeneration ${ }^{[13]}$. The inhibition of GSK-3 $\beta$ also impairs the regeneration of adult rat liver after $\mathrm{PH}^{[15,17]}$. These findings suggest that GSK-3 $\beta$ is essential for liver development and regeneration in vivo. However, Ito et al reported that the concurrent inhibition of GSK-3 $\beta$ and TGF- $\beta$ can induce the proliferation of mature hepatocytes in vitro ${ }^{[18]}$.

The present study showed a negative regulatory role for GSK-3 $\beta$ in liver oval cell proliferation. We use the pharmacological GSK-3 $\beta$-specific inhibitor SB216763 to inhibit the activity of GSK-3 $\beta$ in WB-F344 cells. SB216763 inhibits the activity of GSK-3 $\beta$ by phosphorylating Ser9 at the N-terminus ${ }^{[26]}$ but does not affect the total level of GSK-3 $\beta$. GSK-3 $\beta$ inhibition significantly increased the proliferation of WB-F344 cells. The downregulation of GSK-3 $\beta$ using a lentivirus also promoted WB-F344 cell proliferation. Consistently, overexpressing GSK-3 $\beta$ with a lentivirus inhibited cell proliferation. Finally, we assessed the effect of GSK-3 $\beta$ inhibition on oval cell proliferation in vivo. The results in rats with $\mathrm{PH}$ were consistent with the in vitro findings: treatment with the GSK-3 $\beta$ inhibitor dramatically increased the expression of phospho-Ser'GSK-3 $\beta$, and promoted the proliferation of oval cells and liver regeneration. The different regulatory roles for GSK-3 $\beta$ between hepatocytes and oval cells suggest that GSK-3 $\beta$ modulates the proliferation of these cells through different signaling pathways.

GSK-3 $\beta$ is known to modulate cell survival and apoptosis through multiple intracellular signaling pathways ${ }^{[27]}$. GSK-3 $\beta$ also plays an important role in canonical Wnt signalling pathway, which is essential for self-renewal of many stem cells, including hepatic progenitors ${ }^{[28]}$. GSK-3 $\beta$ exists in a multimeric complex with APC, axin and $\beta$-catenin, where GSK-3 $\beta$ phosphorylates the $\mathrm{N}$ terminal Ser/Thr of $\beta$-catenin leading to its degradation mediated by ubiquitin/proteasomes ${ }^{[2,30]}$. Activation of Wnt signalling leads to GSK-3 $\beta$ inactivation resulting in dephosphorylation and stabilization of $\beta$-catenin protein in the cytosol. The increased levels of $\beta$-catenin lead to its nuclear translocation, and its interaction with transcription factors LEF/TCF (lymphoid enhancer factor/T cell factor) activate the expression of target genes like c-myc and cyclin D1, leading to an increase in cell proliferation ${ }^{[27,31]}$. Several recent studies in rodents have elucidated the role of Wnt/ $\beta$-catenin signaling in oval cell activation and proliferation. Wnt/ $\beta$-catenin signaling is induced in the livers of mice exposed to DDC, and oval cells isolated from DDC-exposed livers display nuclear localization of $\beta$-catenin in response to Wnt3a stimula$\operatorname{tion}^{[32]}$. In rats, $\mathrm{Wnt} / \beta$-catenin signaling is also activated by $2 \mathrm{AAF} / \mathrm{PH}^{[33]}$. Moreover, the activation of $\beta$-catenin signaling in response to Wnt ligands was recently observed in WB-F344 cells, resulting in their proliferation ${ }^{[34]}$.

In another study, the significant upregulation of several Wnt genes was accompanied by increased levels of active $\beta$-catenin in mice exposed to DDC. The activation of the $\mathrm{Wnt} / \beta$-catenin signaling pathway in vitro is sufficient to induce proliferation of cultured hepatic stem/progenitor cells ${ }^{[35]}$. GSK-3 $\beta$ has been implicated in the regulation of the Wnt/ $\beta$-catenin signaling pathway ${ }^{[36]}$. In canonical Wnt signaling, the extracellular ligand Wnt causes the inactivation of GSK-3 $\beta$, resulting in $\beta$-catenin activation ${ }^{[37,38]}$. Wnt signaling can also be activated by direct intracellular inhibition of GSK-3 function using specific inhibitors ${ }^{[39,40]}$.

Our results demonstrate that inhibiting the activity of GSK-3 $\beta$ with a pharmacological inhibitor or downregulating GSK-3 $\beta$ expression with a lentivirus can increase the level of $\beta$-catenin and cyclin D1. In contrast, overexpressing GSK-3 $\beta$ with a lentivirus in cultured WB-F344 cells downregulates $\beta$-catenin and cyclin D1. It was reported that the proliferation of WB-F344 cells is severely impaired in the absence of $\beta$-catenin and that they show a decreased expression of downstream targets such as cyclin $\mathrm{D} 1^{[41]}$. Together, these findings lead us to hypothesize that GSK-3 $\beta$ modulates rat hepatic oval cell proliferation through $\mathrm{Wnt} / \beta$-catenin signaling.

In conclusion, the current study shows that GSK-3 $\beta$ plays an important role in the proliferation of rat hepatic oval cells, which is complementary to Wnt/ $\beta$-catenin signaling in modulating oval cell proliferation. These findings indicate the potential for developing GSK-3 $\beta$ inhibitors to promote liver regeneration.

\section{Acknowledgements}

This study was supported by the National Natural Science Foundation of China (№ 30700800) and Zhejiang Extremely Key Subject of Surgery. We thank Ka-te HUANG and Li WAN for their technical assistance with the immunohistochemistry.

\section{Author contribution}

Qi-yu ZHANG and Yun-feng SHAN designed the research; Xiao-ke JI, Yuan-kang XIE, and Jun-qiao ZHONG performed the research; Qi-gang XU and Qi-qiang ZENG analyzed the 
data; and Xiao-ke JI and Yang WANG wrote the paper.

\section{References}

1 Fausto N, Campbell JS. The role of hepatocytes and oval cells in liver regeneration and repopulation. Mech Dev 2003; 120: 117-30.

2 Petersen BE, Goff JP, Greenberger JS, Michalopoulos GK. Hepatic oval cells express the hematopoietic stem cell marker Thy-1 in the rat. Hepatology 1998; 27: 433-45.

3 Paku S, Nagy P, Kopper L, Thorgeirsson SS. 2-Acetylaminofluorene dose-dependent differentiation of rat oval cells into hepatocytes: confocal and electron microscopic studies. Hepatology 2004; 39: 1353-61.

4 Wang X, Foster M, Al-Dhalimy M, Lagasse E, Finegold M, Grompe M. The origin and liver repopulating capacity of murine oval cells. Proc Natl Acad Sci U S A 2003; 100: 11881-8.

5 Lemire JM, Shiojiri N, Fausto N. Oval cell proliferation and the origin of small hepatocytes in liver injury induced by D-galactosamine. Am J Pathol 1991; 139: 535-52.

6 Dabeva MD, Shafritz DA. Activation, proliferation, and differentiation of progenitor cells into hepatocytes in the D-galactosamine model of liver regeneration. Am J Pathol 1993; 143: 1606-20.

7 Evarts RP, Hu Z, Omori N, Omori M, Marsden ER, Thorgeirsson SS. Precursor-product relationship between oval cells and hepatocytes: comparison between tritiated thymidine and bromodeoxyuridine as tracers. Carcinogenesis 1996; 17: 2143-51.

8 Roskams TA, Libbrecht L, Desmet VJ. Progenitor cells in diseased human liver. Semin Liver Dis 2003; 23: 385-96.

9 Masson NM, Currie IS, Terrace JD, Garden OJ, Parks RW, Ross JA. Hepatic progenitor cells in human fetal liver express the oval cell marker Thy-1. Am J Physiol Gastrointest Liver Physiol 2006; 291 : G45-54.

10 Woodgett JR, Cohen P. Multisite phosphorylation of glycogen synthase. Molecular basis for the substrate specificity of glycogen synthase kinase-3 and casein kinase-II (glycogen synthase kinase-5). Biochim Biophys Acta 1984; 788: 339-47.

11 Woodgett JR. Molecular cloning and expression of glycogen synthase kinase-3/factor A. EMBO J 1990; 9: 2431-8.

12 Rayasam GV, Tulasi VK, Sodhi R, Davis JA, Ray A. Glycogen synthase kinase 3: more than a namesake. Br J Pharmacol 2009; 156: 88598.

13 Hoeflich KP, Luo J, Rubie EA, Tsao MS, Jin O, Woodgett JR. Requirement for glycogen synthase kinase-3beta in cell survival and NF-kappaB activation. Nature 2000; 406: 86-90.

14 Jin J, Wang GL, Shi X, Darlington GJ, Timchenko NA. The ageassociated decline of glycogen synthase kinase 3beta plays a critical role in the inhibition of liver regeneration. Mol Cell Biol 2009; 29 : 3867-80.

15 Chen H, Yang S, Yang Z, Ma L, Jiang D, Mao J, et al. Inhibition of GSK3beta decreases NF-kappaB-dependent gene expression and impairs the rat liver regeneration. J Cell Biochem 2007; 102: 1281-9.

16 Desbois-Mouthon C, Blivet-Van EMJ, Beurel E, Boissan M, Delelo R, Cadoret $\mathrm{A}$, et al. Dysregulation of glycogen synthase kinase-3beta signaling in hepatocellular carcinoma cells. Hepatology 2002; 36: 1528-36.

17 Sekiya S, Suzuki A. Glycogen synthase kinase 3 beta-dependent Snail degradation directs hepatocyte proliferation in normal liver regeneration. Proc Natl Acad Sci U S A 2011; 108: 11175-80.

18 Ito H, Kamiya A, Ito K, Yanagida A, Okada K, Nakauchi H. In vitro expansion and functional recovery of mature hepatocytes from mouse adult liver. Liver Int 2012; 32: 592-601.
19 Coleman WB, McCullough KD, Esch GL, Faris RA, Hixson DC, Smith GJ, et al. Evaluation of the differentiation potential of WB-F344 rat liver epithelial stem-like cells in vivo. Differentiation to hepatocytes after transplantation into dipeptidylpeptidase-IV-deficient rat liver. Am J Pathol 1997; 151: 353-9.

20 Couchie D, Holic N, Chobert MN, Corlu A, Laperche Y. In vitro differentiation of WB-F344 rat liver epithelial cells into the biliary lineage. Differentiation 2002; 69: 209-15.

21 Thorgeirsson SS, Grisham JW. Overview of recent experimental studies on liver stem cells. Semin Liver Dis 2003; 23: 303-12.

22 Tsao MS, Smith JD, Nelson KG, Grisham JW. A diploid epithelial cell line from normal adult rat liver with phenotypic properties of 'oval' cells. Exp Cell Res 1984; 154: 38-52.

23 Bisgaard HC, Nagy P, Santoni-Rugiu E, Thorgeirsson SS. Proliferation, apoptosis, and induction of hepatic transcription factors are characteristics of the early response of biliary epithelial (oval) cells to chemical carcinogens. Hepatology 1996; 23: 62-70.

24 Alison MR, Golding M, Sarraf CE, Edwards RJ, Lalani EN. Liver damage in the rat induces hepatocyte stem cells from biliary epithelial cells. Gastroenterology 1996; 110: 1182-90.

25 Duncan AW, Dorrell C, Grompe M. Stem cells and liver regeneration. Gastroenterology 2009; 137: 466-81.

26 Meijer L, Flajolet M, Greengard P. Pharmacological inhibitors of glycogen synthase kinase 3. Trends Pharmacol Sci 2004; 25: 47180.

27 Jope RS, Johnson GV. The glamour and gloom of glycogen synthase kinase-3. Trends Biochem Sci 2004; 29: 95-102.

28 Plumpe J, Malek NP, Bock CT, Rakemann T, Manns MP, Trautwein C. NF-kappaB determines between apoptosis and proliferation in hepatocytes during liver regeneration. Am J Physiol Gastrointest Liver Physiol 2000; 278: G173-83.

29 Rubinfeld B, Albert I, Porfiri E, Fiol C, Munemitsu S, Polakis P. Binding of GSK3beta to the APC-beta-catenin complex and regulation of complex assembly. Science 1996; 272: 1023-6.

30 Chen RH, Ding WV, McCormick F. Wnt signaling to betacatenin involves two interactive components. Glycogen synthase kinase-3beta inhibition and activation of protein kinase C. J Biol Chem 2000; 275: 7894-9.

31 Patel S, Doble B, Woodgett JR. Glycogen synthase kinase-3 in insulin and Wnt signalling: a double-edged sword? Biochem Soc Trans 2004; 32: 803-8.

32 Nusse R, Fuerer C, Ching W, Harnish K, Logan C, Zeng A, et al. Wnt signaling and stem cell control. Cold Spring Harb Symp Quant Biol 2008; 73: 59-66.

$33 \mathrm{Hu}$ M, Kurobe M, Jeong YJ, Fuerer C, Ghole S, Nusse R, et al. Wnt/ beta-catenin signaling in murine hepatic transit amplifying progenitor cells. Gastroenterology 2007; 133: 1579-91.

34 Apte U, Thompson MD, Cui S, Liu B, Cieply B, Monga SP. Wnt/betacatenin signaling mediates oval cell response in rodents. Hepatology 2008; 47: 288-95.

35 Zhang Y, Li XM, Zhang FK, Wang BE. Activation of canonical Wnt signaling pathway promotes proliferation and self-renewal of rat hepatic oval cell line WB-F344 in vitro. World J Gastroenterol 2008; 14: $6673-80$.

36 Itoh T, Kamiya Y, Okabe M, Tanaka M, Miyajima A. Inducible expression of Wnt genes during adult hepatic stem/progenitor cell response. FEBS Lett 2009; 583: 777-81.

37 Yost C, Torres M, Miller JR, Huang E, Kimelman D, Moon RT. The axisinducing activity, stability, and subcellular distribution of beta-catenin is regulated in Xenopus embryos by glycogen synthase kinase 3 . 
Genes Dev 1996; 10: 1443-54.

38 van Es JH, Barker N, Clevers H. You Wht some, you lose some: oncogenes in the Wnt signaling pathway. Curr Opin Genet Dev 2003; 13: 28-33.

39 Moon RT, Bowerman B, Boutros M, Perrimon N. The promise and perils of Wnt signaling through beta-catenin. Science 2002; 296:1644-6.
40 Sato N, Meijer L, Skaltsounis L, Greengard P, Brivanlou AH. Maintenance of pluripotency in human and mouse embryonic stem cells through activation of Wnt signaling by a pharmacological GSK-3specific inhibitor. Nat Med 2004; 10: 55-63.

41 Doble BW, Woodgett JR. GSK-3: tricks of the trade for a multi-tasking kinase. J Cell Sci 2003; 116: 1175-86. 